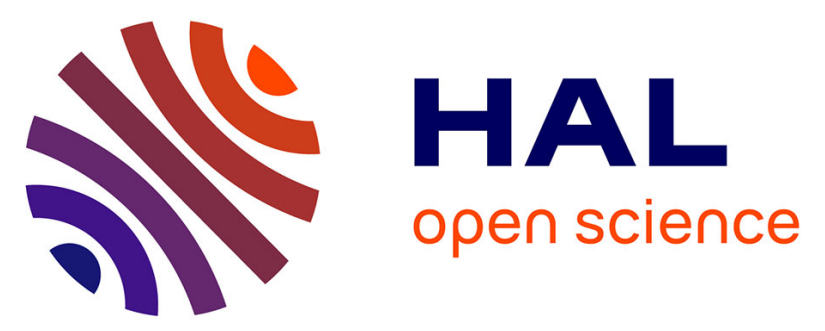

\title{
Identification of outer membrane proteins of Vibrio parahaemolyticus and Vibrio alginolyticus altered in response to $\gamma$-irradiation or long-term starvation.
}

Fethi Ben Abdallah, Ali Ellafi, Rihab Lagha, Amina Bakhrouf, Abdelkader Namane, Jean-Claude Rousselle, Pascal Lenormand, Héla Kallel

\section{To cite this version:}

Fethi Ben Abdallah, Ali Ellafi, Rihab Lagha, Amina Bakhrouf, Abdelkader Namane, et al.. Identification of outer membrane proteins of Vibrio parahaemolyticus and Vibrio alginolyticus altered in response to $\gamma$-irradiation or long-term starvation.. Research in Microbiology, 2010, 161 (10), pp.86975. 10.1016/j.resmic.2010.10.009 . pasteur-01375303

\section{HAL Id: pasteur-01375303 \\ https://hal-riip.archives-ouvertes.fr/pasteur-01375303}

Submitted on 3 Jan 2017

HAL is a multi-disciplinary open access archive for the deposit and dissemination of scientific research documents, whether they are published or not. The documents may come from teaching and research institutions in France or abroad, or from public or private research centers.
L'archive ouverte pluridisciplinaire HAL, est destinée au dépôt et à la diffusion de documents scientifiques de niveau recherche, publiés ou non, émanant des établissements d'enseignement et de recherche français ou étrangers, des laboratoires publics ou privés. 


\title{
Identification of outer membrane proteins of Vibrio parahaemolyticus and Vibrio alginolyticus altered in response to $\gamma$-irradiation or long-term starvation
}

\author{
Fethi Ben Abdallah ${ }^{\mathrm{a}, \mathrm{b}, *}$, Ali Ellafi ${ }^{\mathrm{a}}$, Rihab Lagha ${ }^{\mathrm{a}}$, Amina Bakhrouf ${ }^{\mathrm{a}}$, Abdelkader Namane ${ }^{\mathrm{c}}$, \\ Jean-Claude Rousselle ${ }^{\mathrm{c}}$, Pascal Lenormand ${ }^{\mathrm{c}}$, Héla Kallel ${ }^{\mathrm{b}}$ \\ ${ }^{a}$ Laboratoire d'Analyse, Traitement et Valorisation des Polluants de l'Environnement et des Produits, Faculté de Pharmacie, Rue Avicenne, Monastir 5000, Tunisia \\ ${ }^{\mathrm{b}}$ Unité de Fermentation et de Développement de Vaccins Virologiques, Institut Pasteur de Tunis, 13 place Pasteur 1002, Tunisia \\ ${ }^{\mathrm{c}}$ Institut Pasteur, Plate-Forme de Protéomique, CNRS URA 2185, 28 Rue du Docteur Roux, 75724, Paris Cedex 15, France
}

Received 1 June 2010; accepted 30 August 2010

Available online 28 October 2010

\begin{abstract}
Vibrio parahaemolyticus and Vibrio alginolyticus were subjected to $\gamma$-irradiation $(0.5 \mathrm{kGy})$ or starvation by incubation for 8 months in seawater to study modifications in their outer membrane protein patterns. After treatment, outer membrane protein profiles of starved or $\gamma$-irradiated bacteria were found to be altered when analyzed by sodium dodecyl sulfate polyacrylamide gel electrophoresis (SDS-PAGE). Altered proteins were identified by mass spectrometry (MS and MS/MS) and analyses revealed that OmpU can be considered a starvation stress-induced protein. In addition, expression of OtnA, OmpW, OmpA and peptidoglycan-associated lipoprotein decreased to non-detectable levels in starved cells. Furthermore, MltA-interacting protein MipA appeared under $\gamma$-irradiation or starvation conditions. Thus, it can be considered to be a $\gamma$-irradiation, long-term starvation stress protein in some vibrios.
\end{abstract}

(C) 2010 Institut Pasteur. Published by Elsevier Masson SAS. All rights reserved.

Keywords: Vibrio; Starvation; $\gamma$-Irradiation; Alteration; Outer membrane proteins; Mass spectrometry

\section{Introduction}

Vibrio, a food-borne pathogen, can sense and respond to changes in its external environment (Ben Kahla et al., 2008). The ability of Vibrio spp. to sense and respond effectively to changes in the environment is crucial for their survival (Morita, 1997). One such environmental parameter is the nutrient quantity in the extracellular medium. In general, microorganisms do not respond to nutrient deprivation or starvation by simply arresting all metabolic activities and stopping growth. Instead, they carry out starvation-induced

\footnotetext{
* Corresponding author. Laboratoire d'Analyse, Traitement et Valorisation des Polluants de l'Environnement et des Produits, Faculté de Pharmacie, Rue Avicenne, Monastir 5000, Tunisia. Tel.: +21 673466 244; fax: +21 673461 830.

E-mail address: fetyben@yahoo.fr (F. Ben Abdallah).
}

activities that may include production of degradative enzymes and stress proteins (Siegele and Kolter, 1992). During nutrient deficiency, Vibrio spp. can survive for a long time by sequential changes in cell physiology and gradual changes in morphology (Morita, 1997). Srinivasan and Kjellberg (1998) found that, under starvation in natural environments, the response of vibrios indicated that the life cycle of bacteria broadly consisted of two major phases. The transition between these two major phases involves dramatic changes in gene expression, physiology and morphology.

Recently, gamma irradiation technology has shown positive effects in preventing decay by sterilizing microorganisms and improving the safety and shelf-stability of food products without compromising the nutritional or sensory quality (Lee et al., 2006). Andrews et al. (2003) reported that naturally incurred Vibrio vulnificus in oysters was reduced to nondetectable levels with ${ }^{60}$ cobalt gamma radiation treatment at 
$0.75 \mathrm{kGy}$. Treatment of oysters inoculated with Vibrio parahaemolyticus $\mathrm{O} 3: \mathrm{K} 6$ with $1.0-1.5$ kGy also reduced contamination to non-detectable levels. Gamma irradiation causes damage to the DNA of cells (Villavicencio et al., 2004; Lee and Levin, 2008). The types of DNA damage experienced may be: i) direct physical effects of ionizing radiation with primary free radicals, and indirect biochemical effects from reactive oxygen species resulting in double-strand breaks; ii) single-strand breaks; and iii) base pair substituting mutations due to the conversion of pyrimidine bases to 5-(hydroxymethyl) uracil, 5-formyluracil, 5-hydroxycytosine, and 5-hydroxyuracil (Jung, 1997; Lydersen and Pettijohn, 1997; Min et al., 2000)

In Gram-negative bacteria, the outer membrane plays an important role in infection and pathogenicity toward the host (Tsolis, 2002). In the outer membrane, proteins play a crucial role during many cellular and physiological processes (Qian et al., 2008). Outer membrane proteins (OMPs) play a key role in adaptation to changes of external environments due to their location at the outermost area of the cell (Xu et al., 2005). It has been shown that when bacteria are transferred to a new environment, the synthesis of their OMPs changes (Kustos et al., 2007). In this way, Wu et al. (2006) demonstrated that $\mathrm{OmpW}$ and $\mathrm{OmpV}$ are required for environmental salt regulation in Photobacterium damsela. Furthermore, the altered osmolarity of the culture medium caused changes in the OMP patterns of Vibrio alginolyticus (Xu et al., 2005) and V. parahaemolyticus (Xu et al., 2004).

The aim of this work was to study modifications in the OMPs profiles of starved or gamma-irradiated $V$. parahaemolyticus and $V$. alginolyticus strains. OMPs profiles were analyzed by sodium dodecyl sulfate polyacrylamide gel electrophoresis (SDS-PAGE). In order to identify altered OMPs, mass spectrometry (MS and MS/MS) was used.

\section{Materials and methods}

\subsection{Bacterial strains}

Six Vibrio strains were used in this study, including three reference strains: V. alginolyticus ATCC 33787 (S1), V. alginolyticus ATCC 17749 (S2) and V. parahaemolyticus ATCC 17802 (S5). In addition, V. parahaemolyticus strain (S6) isolated from the Calich estuary (Alghero, Italy) and two $V$. alginolyticus strains (S3 and S4) isolated, respectively, from the internal organs of aquacultured-diseased gilthead sea bream (Sparus aurata) and sea bass (Dicentrarchus labrax) in a Tunisian aquaculture farm (Ben Abdallah et al., 2009) were included in this work.

\subsection{Starvation stress}

$V$. alginolyticus and $V$. parahaemolyticus were grown at $30{ }^{\circ} \mathrm{C}$ in tryptic soy broth (Pronadisa, Spain) supplement with $1 \% \mathrm{NaCl}$ (TSB 1\%) for $24 \mathrm{~h}$. The natural seawater $(100 \mathrm{ml})$ was sterilized by membrane filtration (pore size, $0.22 \mu \mathrm{m}$; Millipore Corp., Bedford, MA, USA) and autoclaving $\left(121{ }^{\circ} \mathrm{C}\right.$ for $20 \mathrm{~min})$. Vibrio cells were washed three times $(13,000 \mathrm{rpm}$ for $10 \mathrm{~min}$ at $20^{\circ} \mathrm{C}$ ) and then suspended in $10 \mathrm{ml}$ of sterilized seawater. The microcosms $(100 \mathrm{ml})$ were inoculated with these suspensions $\left(10^{9}\right.$ Colony Forming Unit $\left.(\mathrm{CFU}) / \mathrm{ml}\right)$ and then incubated at room temperature $\left(22-25^{\circ} \mathrm{C}\right)$ for 8 months.

\subsection{Gamma irradiation treatment}

$V$. alginolyticus and $V$. parahaemolyticus tested strains were cultivated at $30{ }^{\circ} \mathrm{C}$ in TSB $1 \%$ with shaking $(150 \mathrm{rpm})$. The cultures of Vibrio strains grown to late log phase (O.D.600 = 0.6) were divided into $1 \mathrm{ml}$ aliquots without change of broth and were exposed, in triplicate, on ice to a ${ }^{60}$ cobalt $\gamma$-irradiator (point source, AECL, IR-79, Technopole, Sidi Thabet, Tunisia). The applied dose was $0.5 \mathrm{kGy}$. The control cells were introduced in ice during the time of irradiation. The irradiated and non-irradiated Vibrio were diluted 50 -fold by using $50 \mathrm{ml}$ of fresh medium and then harvested after $24 \mathrm{~h}$ of incubation at $30{ }^{\circ} \mathrm{C}$ with shaking $(150 \mathrm{rpm})$.

\subsection{Outer membrane protein extraction}

OMPs of V. alginolyticus and V. parahaemolyticus, before and after irradiation, were prepared according to the method described previously (Sabri et al., 2000). Briefly, the bacterial cells were harvested by centrifugation at $4000 \times g$ for $15 \mathrm{~min}$ at $4{ }^{\circ} \mathrm{C}$. The cells were then washed three times in $40 \mathrm{ml}$ of sterile saline water $(0.9 \% \mathrm{NaCl})$ and then resuspended in $5 \mathrm{ml}$ sterile saline water. Cells were disrupted by intermittent sonic oscillation in ice bath $(350 \mathrm{~W}, 10 \mathrm{~min} \times 3)$. Unbroken cells and cellular debris were removed by centrifugation at $5000 \times g$ for $20 \mathrm{~min}$. Supernatant was collected and was further centrifuged at $100000 \times g$ for $40 \mathrm{~min}$ at $4{ }^{\circ} \mathrm{C}$. The pellet was resuspended in $10 \mathrm{ml}$ of $2 \%$ (w/v) sodium lauryl sarcosinate (Sigma, St Louis, MO) and incubated at room temperature for $1 \mathrm{~h}$, followed by centrifugation at $100000 \times g$ for $40 \mathrm{~min}$ at $4{ }^{\circ} \mathrm{C}$. The resulting pellet was resuspended in $200 \mu \mathrm{l}$ of sterile saline water. The concentration of the OMPs in the final preparation was determined using the Bradford Kit (Sigma).

\subsection{SDS-PAGE}

OMPs of starved $(2 \mu \mathrm{g})$ and $\gamma$-irradiated $(1 \mu \mathrm{g}) V$. alginolyticus and V. parahaemolyticus were analyzed in triplicate by SDS-PAGE (Laemmli, 1970) with 15\% acrylamide in the separating gel and 5\% acrylamide in the stacking gel. After separation, the proteins were visualized according to standard procedures by staining with Coomassie brilliant blue G250 (Sigma).

\subsection{Protein identification by $M S$}

After staining with colloidal Coomassie blue, 1D gel bands were manually excised from gels and collected in a 96-well plate. Destaining, reduction, alkylation and trypsin digestion of the proteins followed by peptide extraction were carried out 
with the Progest Investigator (Genomic Solutions, Ann Arbor, MI, USA). After the desalting step (C18- $\mu$ ZipTip, Millipore), peptides were eluted directly using the ProMS Investigator, (Genomic Solutions, Ann Arbor, MI, USA) onto a 96-well stainless steel MALDI target plate (Applied Biosystems/MDS SCIEX, Framingham, MA, USA) with $0.5 \mu \mathrm{l}$ of $\alpha$-ciano4-hydroxycinnamic acid (CHCA) matrix $(2.5 \mathrm{mg} / \mathrm{ml}$ in $70 \%$ acetonitril $(\mathrm{ACN}) / 30 \% \mathrm{H}_{2} \mathrm{O} / 0.1 \%$ trifluoracetic (TFA)).

\section{7. $M S$ and $M S / M S$ analysis}

Raw data for protein identification were obtained on the 4800 MALDI TOF/TOF Analyzer (Applied Biosystems/MDS SCIEX, Framingham, MA, USA) and were analyzed by GPS Explorer 3.6 software (Applied Biosystems/MDS SCIEX, Framingham, MA, USA). For positive-ion reflector mode spectra 3000 laser shots were averaged. Autolysis peaks of trypsin $([\mathrm{M}+\mathrm{H}]+=842.5100$ and 2211.1046) were used as internal calibrators for MS calibration. Monoisotopic peak masses were automatically determined within the mass range $800-4000 \mathrm{~m} / \mathrm{z}$ with a signal to noise ratio minimum set to 30 . Up to twelve of the most intense ion signals were selected as precursors for MS/MS acquisition, excluding common trypsin autolysis peaks and matrix ion signals. In MS/MS positive ion mode, 4000 spectra were averaged, collision energy was $2 \mathrm{kV}$, collision gas was air and default calibration was set using the Glu1-Fibrino-peptide B $([\mathrm{M}+\mathrm{H}]+=1570.6696)$ spotted onto fourteen positions of the MALDI target. Combined peptide mass fingerprinting (PMF) and MS/MS queries were performed using the MASCOT search engine 2.1 (Matrix Science Ltd., UK) embedded into GPS Explorer Software 3.6 (Applied Biosystems/MDS SCIEX, Framingham, MA, USA) on the UNIPROT database (downloaded 200906 25; 9064751 sequences; 2941541906 residues) with the following parameter settings: $50 \mathrm{ppm}$ peptide mass accuracy, trypsin cleavage, one missed cleavage allowed, carbamidomethylation set as fixed modification, oxidation of methionine was allowed as variable modification, MS/MS fragment tolerance was set to 0.3 Da. Protein hits with MASCOT Protein score $\geq 82$ and a GPS Explorer Protein confidence index $=95 \%$ were used for further manual validation.

\section{Results}

\subsection{Effect of starvation on OMPs}

OMPs of the four starved $V$. alginolyticus and two V. parahaemolyticus cells were analyzed by SDS-PAGE (Fig. 1) and MS (Table 1). Before their incubation in seawater, each Vibrio strain presents its specific OMPs profile. In addition, almost 15 bands were detected in each profile containing from three to six major OMPs. After 8 months of incubation in seawater, we noted that only $V$. alginolyticus ATCC 33787 (S1) and $V$. parahaemolyticus (S6), isolated from the Calich estuary (Alghero), preserved their initial OMPs profiles. Whereas, for V. alginolyticus ATCC 17749 (S2), we observed that the band corresponding to porin, putative and long-chain fatty acid transport protein was reduced, whereas OmpU became less abundant after starvation. Similar results have been observed in starved V. parahaemolyticus ATCC 17802 (S5), which respond to nutrient limitation by increasing the expression of OmpU. The major alterations in the OMP profile of the studied strains were observed in the two V. alginolyticus strains S3 and $\mathrm{S} 4$ isolated from the internal organs of aquacultured-diseased gilthead sea bream and sea bass, respectively. For strain S3, five bands were distinctly altered, showing that expression of OtnA, OmpW and peptidoglycan-associated lipoprotein decreased to non-detectable levels. In addition, the expression of OmpU was induced and the abundance of OmpK and outer membrane protein was decreased. In the OMPs profile of the

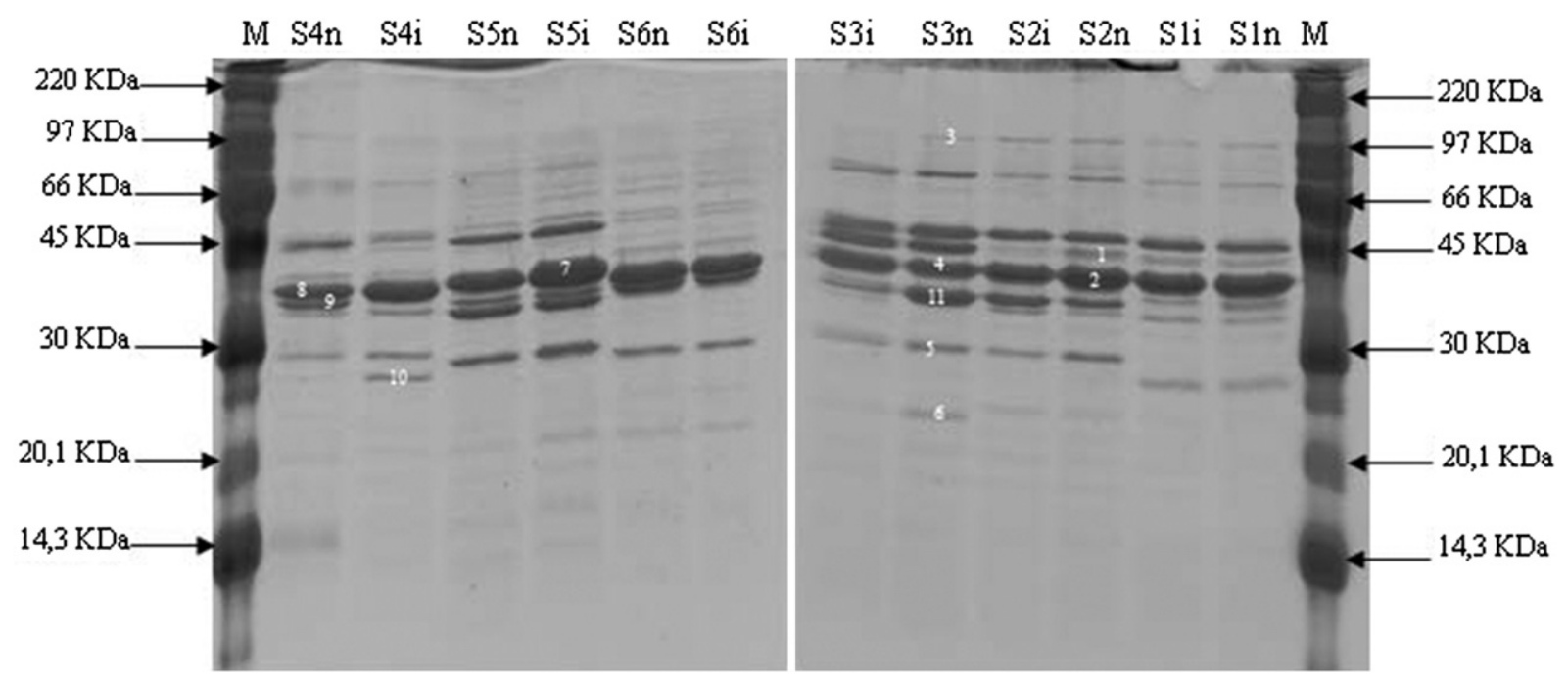

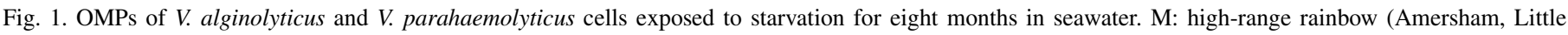

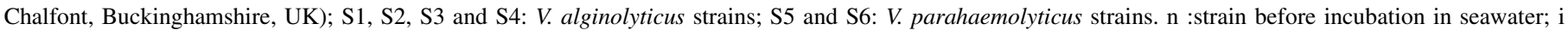
:strain incubated for eight months in seawater microcosms. 
Table 1

List of altered OMPs of starved $V$. alginolyticus and $V$. parahaemolyticus identified using MS-MS/MS.

\begin{tabular}{|c|c|c|c|c|c|c|}
\hline Strain & Band number & Identified protein & Accession number (Uniprot) & $\begin{array}{l}\text { Mascot } \\
\text { score }\end{array}$ & $\begin{array}{l}\text { Molecular } \\
\text { mass (Da) }\end{array}$ & $\begin{array}{l}\text { Expression } \\
\text { level }\end{array}$ \\
\hline \multirow[t]{3}{*}{$\mathrm{S} 2$} & 01 & Long-chain fatty acid transport protein & Q1VA77|Q1VA77_VIBAL & 175 & 46030.4 & - \\
\hline & & Porin, putative & A7K0N2|A7K0N2_9VIBR & 487 & 39676 & - \\
\hline & 02 & Outer membrane protein OmpU & Q1V395|Q1V395_VIBAL & 728 & 37067.4 & - \\
\hline \multirow[t]{6}{*}{ S3 } & 03 & OtnA protein & Q1V7L9|Q1V7L9_VIBAL & 605 & 99671.3 & - \\
\hline & 04 & Outer membrane protein $\mathrm{OmpU}$ & Q1V395|Q1V395_VIBAL & 641 & 37067.4 & + \\
\hline & 05 & Outer membrane protein $=$ Ompk & Q4PNS4|Q4PNS4_VIBAL & 477 & 31311.9 & - \\
\hline & 06 & Peptidoglycan-associated lipoprotein & Q1V5X7|Q1V5X7_ VIBAL & 237 & 18740.4 & - \\
\hline & & Outer membrane protein OmpW & Q58IE1|Q58IE1_VIBAL & 122 & 23315.6 & - \\
\hline & 11 & Outer membrane protein & A7JZ07|A7JZ07_9 VIBR & 375 & 36074.2 & - \\
\hline \multirow[t]{4}{*}{ S4 } & 08 & Outer membrane protein $=\mathrm{OmpU}$ & Q4ZIM7|Q4ZIM7_VIBPA & 866 & 36189.9 & - \\
\hline & 09 & Outer membrane protein OmpA & Q1VAZ6|Q1VAZ6_VIBAL & 246 & 36182.2 & - \\
\hline & 10 & MltA-interacting protein MipA & A7JZF9|A7JZF9_9 VIBR & 336 & 31026.2 & + \\
\hline & 12 & Outer membrane channel protein $=$ tolC & Q1V4T2|Q1V4T2_VIBAL & 395 & 47846.3 & - \\
\hline S5 & 07 & Outer membrane protein OmpU & Q1V395|Q1V395_VIBAL & 368 & 37067.4 & + \\
\hline
\end{tabular}

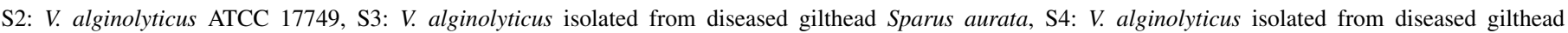
Dicentrarchus labrax, S5 : V. parahaemolyticus ATCC 17802. -: downregulated; +: upregulated.

starved V. alginolyticus (S4), we observed the appearance of MltA-interacting protein MipA, whereas OmpA was decreased to non-detectable levels. Furthermore, OmpU was induced and the expression level of outer membrane channel protein TolC was reduced.

\subsection{Effect of $\gamma$-irradiation on OMPs}

OMPs of $\gamma$-irradiated $V$. alginolyticus and $V$. parahaemolyticus were analyzed by SDS-PAGE (Fig. 2) and MS (Table 2). After $\gamma$-irradiation, several OMPs were altered. Our study showed that only $\gamma$-irradiated $V$. parahaemolyticus (S6) isolated from the Calich estuary (Alghero, Italy) preserved its initial profile of OMPs. For V. alginolyticus (S1, S2 and S4) and $V$. parahaemolyticus (S5), we observed that OmpU became less abundant. Similar results were obtained in V. alginolyticus (S1 and S4) and V. parahaemolyticus (S5), which respond to $\gamma$-irradiation by reducing the expression of OmpA. We also observed a reduction in the expression level of outer membrane channel protein TolC for strains S1, S2, S3 and S4, OMP for strains $\mathrm{S} 2$ and $\mathrm{S} 3$ and maltoporin LamB for V. parahaemolyticus (S5). In V. alginolyticus ATCC 17749 (S2), the expression level of porin, a putative and/or long-chain fatty acid transport protein, was increased. The major alterations in the OMP profile of the studied strains were observed in the two V. alginolyticus $\mathrm{S} 3$ and S4strains isolated from the internal organs of aquacultured-diseased gilthead sea bream and sea bass, respectively. Indeed, in addition to the modifications already cited, we observed that the vitamin B12 receptor and OmpK were decreased to non-detectable levels in $V$. alginolyticus S4, whereas their expression levels were decreased in V. alginolyticus S3. Moreover, peptidoglycan-associated lipoprotein and OmpW were decreased to non-detectable levels in strain S3, whereas MipA was expressed in strain S4.

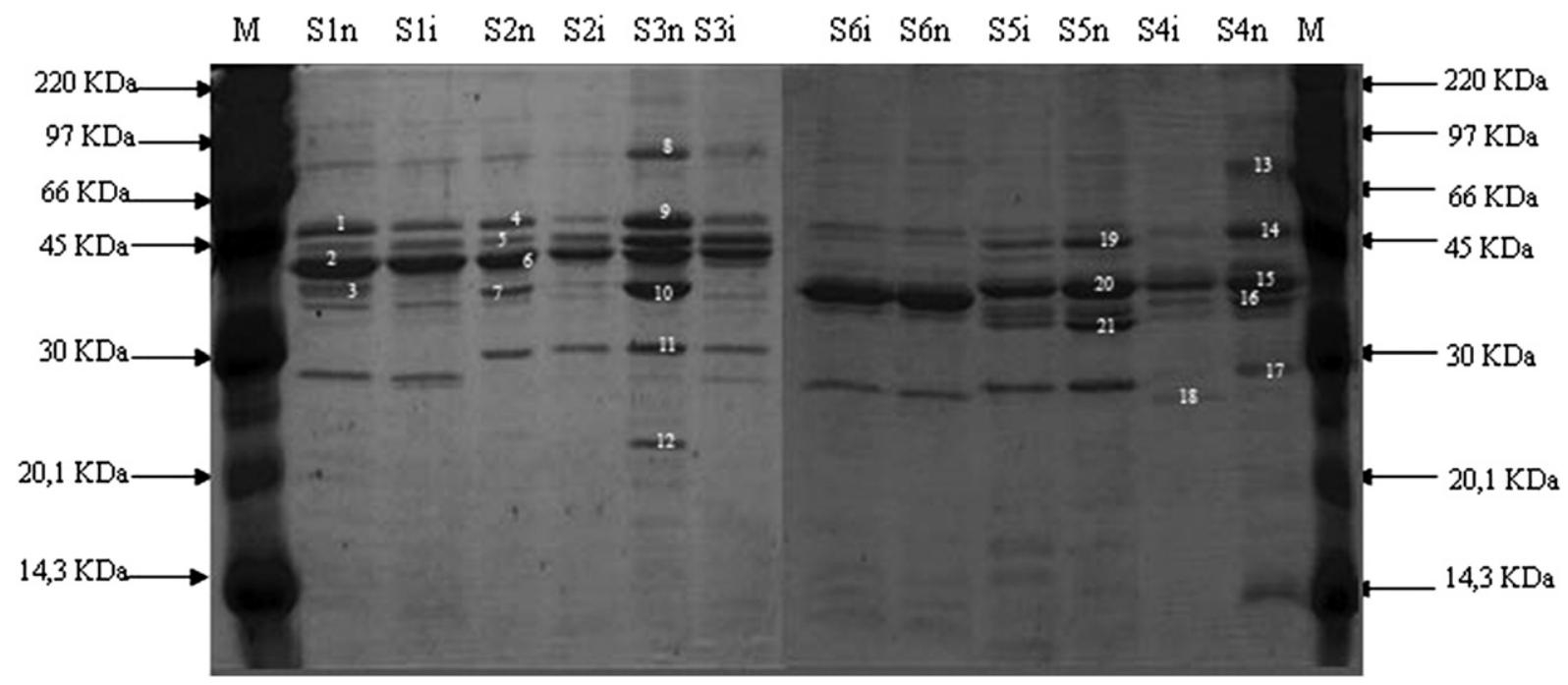

Fig. 2. OMPs of V. alginolyticus and V. parahaemolyticus cells exposed to $\gamma$-irradiation. M, high-range rainbow (Amersham); S1, S2, S3, and S4, V. alginolyticus strains; S5 and S6, V. parahaemolyticus strains; n, strain non-irradiated; i, strain irradiated. 
Table 2

List of altered OMPs of $\gamma$-irradiated V. alginolyticus and V. parahaemolyticus identified using MS-MS/MS.

\begin{tabular}{|c|c|c|c|c|c|c|}
\hline Strain & Band number & Identified protein & Accession number (Uniprot) & $\begin{array}{l}\text { Mascot } \\
\text { score }\end{array}$ & $\begin{array}{l}\text { Molecular } \\
\text { mass (Da) }\end{array}$ & $\begin{array}{l}\text { Expression } \\
\text { level }\end{array}$ \\
\hline \multirow[t]{4}{*}{$\mathrm{S} 1$} & 01 & Outer membrane channel protein $=$ tolC & Q1V4T2|Q1V4T2_VIBAL & 395 & 47846.3 & - \\
\hline & 02 & Outer membrane protein OmpU & Q1V395|Q1V395_VIBAL & 672 & 37067.4 & - \\
\hline & 03 & Outer membrane protein OmpA & Q1VAZ6|Q1VAZ6_VIBAL & 164 & 36182.2 & - \\
\hline & & Putative outer membrane protein & Q1V592|Q1V592_VIBAL & 150 & 37991.1 & - \\
\hline \multirow[t]{5}{*}{ S2 } & 04 & Outer membrane channel protein $=$ tolC & Q1V4T2|Q1V4T2_VIBAL & 475 & 47846.3 & - \\
\hline & 05 & Porin, putative & Q1VA77|Q1VA77_VIBAL & 283 & 39676 & - \\
\hline & & Long-chain fatty acid transport protein & A7K0N2|A7K0N2_9VIBR & 188 & 46030.4 & - \\
\hline & 06 & Outer membrane protein OmpU & Q1V395|Q1V395_VIBAL & 680 & 37067.4 & - \\
\hline & 07 & Outer membrane protein & A7JZ07|A7JZ07_9VIBR & 188 & 36074.2 & - \\
\hline \multirow[t]{6}{*}{ S3 } & 08 & Vitamin B12 receptor & Q1V4E1|Q1V4E1_VIBAL & 1080 & 68061.3 & - \\
\hline & 09 & Outer membrane channel protein $=$ tolC & Q1V4T2|Q1V4T2_VIBAL & 383 & 47846.3 & - \\
\hline & 10 & Outer membrane protein & A7JZ07|A7JZ07_9VIBR & 347 & 36074.2 & - \\
\hline & 11 & Outer membrane protein $=$ Ompk & Q4PNS4|Q4PNS4_VIBAL & 520 & 31311.9 & - \\
\hline & 12 & Peptidoglycan-associated lipoprotein & Q1V5X7|Q1V5X7_VIBAL & 210 & 18740.4 & - \\
\hline & & Outer membrane protein OmpW & Q58IE1|Q58IE1_VIBAL & 145 & 2095.1 & - \\
\hline \multirow[t]{6}{*}{ S4 } & 13 & Vitamin B12 receptor & Q1V4E1|Q1V4E1_VIBAL & 703 & 68061.3 & - \\
\hline & 14 & Outer membrane channel protein $=$ tolC & Q1V4T2|Q1V4T2_VIBAL & 480 & 47846.3 & - \\
\hline & 15 & Outer membrane protein OmpU & Q1V395|Q1V395_VIBAL & 386 & 37067.4 & - \\
\hline & 16 & Outer membrane protein OmpA & Q1VAZ6|Q1VAZ6__VIBAL & 260 & 36182.2 & - \\
\hline & 17 & Outer membrane protein OmpK & Q1VF49|Q1VF49_VIBAL & 107 & 29310 & - \\
\hline & 18 & MltA-interacting protein MipA & A7JZF9|A7JZF9_9 VIBR & 336 & 31026.2 & + \\
\hline \multirow[t]{3}{*}{ S5 } & 19 & Maltoporin $=1 \mathrm{amB}$ & C3W4N2|C3W4N2_VIBPA & 662 & 46349.8 & - \\
\hline & 20 & Outer membrane protein $=\mathrm{ompU}$ & Q4ZIM7|Q4ZIM7_VIBPA & 953 & 36189.9 & - \\
\hline & 21 & Outer membrane protein OmpA & Q87RL4|Q87RL4_VIBPA & 192 & 34165.9 & - \\
\hline
\end{tabular}

S1: V. alginolyticus ATCC 33787, S2: V. alginolyticus ATCC 17749, S3: V. alginolyticus isolated from diseased gilthead Sparus aurata, S4: V. alginolyticus isolated from diseased gilthead Dicentrarchus labrax, S5: V. parahaemolyticus ATCC 17802. -: downregulated; +: upregulated.

\section{Discussion}

All organisms respond to environmental stress by modifying the rate of synthesis of certain proteins. In this study, we observed that long-term starvation or $\gamma$-irradiation induced several alterations in OMPs patterns of marine food-borne pathogens $V$. alginolyticus and $V$. parahaemolyticus cells. These alterations were manifested by the appearance and/or disappearance of proteins as well as in the level of expression of certain proteins.

Modifications observed in cells incubated for 8 months in the seawater microcosm are probably due to nutrient deficiency in seawater. Indeed, it is now clear that changes in the environment induce several alterations in bacterial function and protein expression (Kustos et al., 2007). After the beginning of an adverse effect such as starvation, protein synthesis is inhibited and cell division is interrupted. In parallel, expression of several proteins increases; these are the so-called stress proteins (Kustos et al., 2007). Furthermore, in this study, OmpU can be considered as a starvation-inducible protein, since this protein becomes more abundant in some of the Vibrio strains tested. In addition, MipA was visualized and thus it can also be considered a stress protein in some vibrios. Generally, environmental changes influence the expression of OMPs, and a rise in temperature may induce significant changes in the OMP expression of Escherichia coli (Molloy et al., 2000), Stenotrophomonas maltophilia (RahmatiBahram et al., 1996), Leptospira interrogans serovar Lai (Cullen et al., 2002), Borrelia burgdorferi (Obonyo et al., 2002) and Serratia marcescens (Puig et al., 1993). Martinez et al.
(2001) also found expression of new OMP in E. coli strains by increasing the temperature from 30 to $37^{\circ} \mathrm{C}$. Acidic $\mathrm{pH}$ induced expression of new proteins on the surface of Yersinia pestis (Feodorova and Devdariani, 2001) and OMP expression in B. burgdorferi was also altered at different $\mathrm{pH}$ values (Carroll et al., 1999). Our study showed that expression of OtnA, OmpW, OmpA and peptidoglycan-associated lipoprotein decreased to non-detectable levels when cells were submitted to starvation. It appears that these proteins can be regulated by the availability of nutrients, either directly or indirectly. Studies have shown that the expression of OmpW in Vibrio cholerae was regulated by nutrients and other environmental conditions, including temperature and osmolarity (Nandi et al., 2005). Furthermore, OmpW from V.parahaemolyticus (Xu et al., 2004), $V$. alginolyticus (Xu et al., 2005) and P. damselae (Wu et al., 2006) were all found to be upregulated in high $\mathrm{NaCl}$ concentrations (3.5\% and 4\%). In addition, in this work, several OMPs such as OmpK, outer membrane protein, putative porin and/or long-chain fatty acid transport protein were reduced due to nutrient deprivation. The composition of the culture medium may have significant effects on protein expression. Furthermore, Yoshida et al. (2002) revealed changes in concentrations of OmpR and P, while Contreras et al. (1995) demonstrated an increase in OmpC and a decrease in OmpF expression of E. coli. The effects of magnesium limitation on OMP expression in Pseudomonas aeruginosa (Shand et al., 1988) and Salmonella strains (Hwang et al., 2002) have been also observed.

Our study showed alterations in OMP patterns of V. alginolyticus and $V$. parahaemolyticus after the cells had been 
irradiated. In addition, we did not observe $\gamma$ - induced proteins, since the expression level of all altered OMPs identified was reduced, whereas MipA was detected; therefore, it may be involved in a $\gamma$-irradiation stress response of some vibrios. According to Filali-Mouhim et al. (1997), $\gamma$-irradiation is capable of causing irreversible alterations in protein conformations at the molecular level, such as fragmentation or aggregation. Such an alteration due to $\gamma$-irradiation in aqueous solutions is related to the formation of free radicals by water radiolysis (Assemand et al., 2004). Caillet et al. (2008) reported that $\gamma$-rays influence the synthesis of heat shock proteins in foodborne pathogens in a way that critically depends on the radiation dose.

Many vibrios are pathogenic for humans and/or marine vertebrates and invertebrates (Zhang and Austin, 2005). OMPs, whose production is often regulated by environmental cues, play important roles in bacterial pathogenesis by enhancing the adaptability of the pathogens to various environments. Thus, OMPs contribute to the virulence of bacteria and play essential roles in bacterial adaptation to host niches, which are usually hostile to invading pathogens (Lin et al., 2002). The various alterations observed in the OMP profiles of starved and $\gamma$-irradiated Vibrio reflect the stability of these virulence factors under stress conditions.

In the present study, we noted that alterations in OMPs profiles of vibrios confronted with starvation and $\gamma$-irradiation are variable. Furthermore, based on the number of altered proteins, the effect of $\gamma$-irradiation on expression of OMPs is more accentuated compared to starvation. In addition, compared to $V$. parahaemolyticus, most modifications are observed in V. alginolyticus, and especially strains isolated from the internal organs of aquacultured-diseased gilthead sea bream and sea bass. We also observed that these modifications are variable between the V. alginolyticus cells examined. This might be related to the genomic plasticity of the tested strains.

In summary, starvation or $\gamma$-irradiation causes damage to the expression of OMPs in the foodborne pathogen $V$. alginolyticus and $V$. parahaemolyticus cells. The response of Vibrio to starvation is different from that to $\gamma$-irradiation, but MipA was detected in two cases. This protein can be considered as a $\gamma$-irradiation and long-term starvation stress protein in some vibrios.

\section{References}

Andrews, L., Jahncke, M., Mallikarjunan, K., 2003. Low dose gamma irradiation to reduce pathogenic Vibrio in live oysters (Crassostrea virginica). J. Aquat. Food Prod. Technol. 12, 71-82.

Assemand, E., Lacroix, M., Mateescu, M.A., 2004. Protective role of 1-tyrosine in the sterilization of ceruloplasmin therapeutic protein by gammairradiation. Radiat. Phys. Chem. 71, 403-407.

Ben Abdallah, F., Chaieb, K., Kallel, H., Bakhrouf, A., 2009. RT-PCR assays for in vivo expression of Vibrio alginolyticus virulence genes in cultured gilthead Dicentrarchus labrax and Sparus aurata. Ann. Microbiol. 59, 1-5.

Ben Kahla, N.A., Besbes, A., Bakhrouf, A., 2008. Survival of Vibrio fuvialis in seawater under starvation conditions. Microbiol. Res. 163, 323-328.

Caillet, S., Millette, M., Dussault, D., Shareck, F., Lacroix, M., 2008. Effect of gamma radiation on heat shock protein expression of four foodborne pathogens. J. Appl. Microbiol. 105, 1384-1391.
Carroll, J.A., Garon, C.F., Schwan, T.G., 1999. Effects of environmental pH on membrane proteins in Borrelia burgdorferi. Infect. Immun. 67, 3181-3187.

Contreras, I., Munoz, L., Toro, C.S., Mora, G.C., 1995. Heterologous expression of Escherichia coli porin genes in Salmonella typhi Ty2: regulation by medium osmolarity, temperature and oxygen availability. FEMS. Microbiol. Lett. 133, 105-111.

Cullen, P.A., Cordwell, S.J., Bulach, D.M., Haake, D.A., Adler, B., 2002. Global analysis of outer membrane proteins from Leptospira interrogans serovar Lai. Infect. Immun 70, 2311-2318.

Feodorova, V.A., Devdariani, Z.L., 2001. Expression of acid-stable proteins and modified lipopolysaccharide of Yersinia pestis in acidic growth medium. J. Med. Microbiol. 50, 979-985.

Filali-Mouhim, A., Audette, M., St-Louis, M., Thauvette, L., Denoroy, L., Penin, F., Chen, X., Rouleau, N., Le Caer, J.P., Rossier, J., Potier, M., Le Maire, M., 1997. Lysozyme fragmentation induced by gamma-radiolysis. Int. J. Radiat. Biol. 72, 63-70.

Hwang, P.M., Choy, W.Y., Lo, E.I., Chen, L., Forman-Kay, J.D., Raetz, C.R., Prive, G.G., Bishop, R.E., Kay, L.E., 2002. Solution structure and dynamics of the outer membrane enzyme PagP by NMR. Proc. Natl. Acad. Sci. U S A 99, 13560-13565.

Jung, W.H., 1997. Treatment of Radioisotope and Radiation. Chung-Moon Gack, Seoul, Korea.

Kustos, I., Kocsis, B., Kilar, F., 2007. Bacterial outer membrane protein analysis by electrophoresis and microchip technology. Expert Rev. Proteomics 4, 91-106.

Laemmli, U.K., 1970. Cleavage of structural proteins for the assembly of the head of bacteriophage T4. Nature 227, 680-685.

Lee, J.L., Levin, R.E., 2008. New approach for discrimination of Vibrio vulnificus by real-time PCR before and after gamma-irradiation. J. Microbiol. Methods 73, 1-6.

Lee, N.Y., Jo, C., Shina, D.H., Kim, W.G., Byun, M.W., 2006. Effect of $\gamma$-irradiation on pathogens inoculated into ready-to use vegetables. Food Microbiol. 23, 649-656.

Lin, J., Huang, S., Zhang, Q., 2002. Outer membrane proteins: key players for bacterial adaptation in host niches. Microbes. Infect. 4, 325-331.

Lydersen, B.K., Pettijohn, D.E., 1997. Interactions stabilizing DNA tertiary structure in the Escherichia coli chromosome investigated with ionizing radiation. Chromosoma 62, 199-215.

Martinez, M.B., Flickinger, M., Higgins, L., Krick, T., Nelsestuen, G.L., 2001. Reduced outer membrane permeability of Escherichia coli O157: H7: suggested role of modified outer membrane porins and theoretical function in resistance to antimicrobial agents. Biochemistry 40, 11965-11974.

Min, J., Lee, C.W., Moon, S.H., LaRossa, R.A., Gu, M.B., 2000. Detection of radiation effects using recombinant bioluminescent Escherichia coli strains. Radiat. Environ. Biophys. 39, 41-45.

Molloy, M.P., Herbert, B.R., Slade, M.B., Rabilloud, T., Nouwens, A.S., Williams, K.L., Gooley, A.A., 2000. Proteomic analysis of the Escherichia coli outer membrane. Eur. J. Biochem. 267, 2871-2881.

Morita, R.Y., 1997. Bacteria in Oligotrophic Environments: Starvation Survival Lifestyle. Chapman \& Hall, New York.

Nandi, B., Nandy, R.K., Sarkar, A., Ghose, A.C., 2005. Structural features, properties and regulation of the outer-membrane protein $\mathrm{W}(\mathrm{OmpW})$ of Vibrio cholerae. Microbiology 151, 2975-2986.

Obonyo, M., Munderloh, U.G., Sam, T.N., Kurtti, T.J., 2002. Cultivation at 37 degrees C enhances Borrelia burgdorferi sensu stricto infectivity for hamsters. Med. Microbiol. Immunol. 191, 33-39.

Puig, M., Fuste, C., Vinas, M., 1993. Outer membrane proteins from Serratia marcescens. Can. J. Microbiol. 39, 108-111.

Qian, R., Xiao, Z., Zhang, C., Chu, W., Mao, Z., Yu, L., 2008. Expression and purification of two major outer membrane proteins from Vibrio alginolyticus. World J. Microbiol. Biotechnol. 24, 245-251.

Rahmati-Bahram, A., Magee, J.T., Jackson, S.K., 1996. Temperature-dependent aminoglycoside resistance in Stenotrophomonas (Xanthomonas) maltophilia; alterations in protein and lipopolysaccharide with growth temperature. J. Antimicrob. Chemother. 37, 665-676.

Sabri, M.Y., Zamri-Saad, M., Mutalib, A.R., Israf, D.A., Muniandy, N., 2000. Efficacy of an outer membrane protein of Pasteurella haemolytica A2, A7 
or A9-enriched vaccine against intratracheal challenge exposure in sheep. Vet. Microbiol. 73, 13-23.

Shand, G.H., Anwar, H., Brown, M.R., 1988. Outer membrane proteins of polymyxin resistant Pseudomonas aeruginosa: effect of magnesium depletion. J. Antimicrob. Chemother. 22, 811-821.

Siegele, D.A., Kolter, R., 1992. Life after log. J. Bacteriol. 174, 345-348.

Srinivasan, S., Kjellberg, S., 1998. Cycles of famine and feast: the starvation and outgrowth strategies of a marine Vibrio. J. Biosci. 23, 501-511.

Tsolis, R.M., 2002. Comparative genome analysis of the alpha -proteobacteria: relationships between plant and animal pathogens and host specificity. Proc. Natl. Acad. Sci. U S A 99, 12503-12505.

Villavicencio, A.L.C.H., Araujo, M.M., Marín-Huachaca, N.S., ManciniFilho, J., Delincee, H., 2004. Identification of irradiated refrigerated poultry with the DNA comet assay. Radiat. Phys. Chem. 71, 189-191.
Wu, L., Lin, X., Wang, F., Ye, D., Xiao, X., Wang, S., Peng, X., 2006. OmpW and $\mathrm{OmpV}$ are required for $\mathrm{NaCl}$ regulation in Photobacterium damsela. $\mathrm{J}$. Proteome. Res. 5, 2250-2257.

Xu, C., Ren, H., Wang, S., Peng, X., 2004. Proteomic analysis of salt-sensitive outer membrane proteins of Vibrio parahaemolyticus. Res. Microbiol. 155, $835-842$.

Xu, C., Wang, S., Ren, H., Lin, X., Wu, L., Peng, X., 2005. Proteomic analysis on the expression of outer membrane proteins of Vibrio alginolyticus at different sodium concentrations. Proteomics 5, 3142-3152.

Yoshida, T., Qin, L., Inouye, M., 2002. Formation of the stoichiometric complex of EnvZ, a histidine kinase, with its response regulator, OmpR. Mol. Microbiol. 46, 1273-1282.

Zhang, X.H., Austin, B., 2005. Haemolysins in Vibrio species. J. Appl. Microbiol. 98, 1011-1019. 